\title{
KEMAMPUAN LITERASI MATEMATIKA MAHASISWA DENGAN GAYA BELAJAR SEKUENSIAL DALAM MENYELESAIKAN MASALAH STATISTIKA
}

\author{
${ }^{1}$ Khusnul Khotimah, M.Pd, ${ }^{2}$ M. Farid Nasrulloh, M.Pd \\ email: ${ }^{1}$ khusnulkhotimah@unwaha.ac.id, ${ }^{2}$ faridnasrulloh@unwaha.ac.id
}

\begin{abstract}
Abstrak
Tujuan dari penelitian ini adalah untuk mendeskripsikan kemampuan literasi matematika pada mahasiswa dengan gaya belajar sekuensial dalam menyelesaikan masalah statistika. Penelitian ini merupakan penelitian kualitatif. Proses pengumpulan data dalam penelitian ini dilakukan dengan memberikan angket gaya belajar, memberikan tugas pemecahan masalah, kemudian memilih salah satu hasil tes untuk di deskripsikan. Analisis data dilakukan dengan cara, mengumpulkan data, mereduksi data, dan memverifikasi data.

Hasil yang diperoleh dalam penelitian ini adalah subjek sekuensial memiliki kemampuan literasi pada level 1 yaitu Menggunakan pengetahuan untuk menyelesaikan soal rutin dan namun masih blom dapat menyelesaikan masalah yang konteksnya umum. Subjek sekuensial memiliki kemampuan literasi pada level 2 yaitu dapat menyelesaikan masalah dengan rumus. subyek sekuensial belum bisa Melaksanakan prosedur dengan baik dalam menyelesaikan soal serta belum bisa memilih strategi pemecahan masalah, sesuai dengan level 3. Subjek sekuensial cukup bekerja secara efektif dengan model dan dapat memilih serta mengintegrasikan representasi yang berbeda, kemudian menghubungkannya dengan dunia nyata sesuai dengan level 4.Subjek sekuensial memiliki kemampuan literasi pada level 5 yaitu Bekerja dengan model untuk situasi yang kompleks. Subyek telah dapat menunjukkan variasi ketahanan yang lebih baik dengan koefisien variasi, namun belum mampu menggunakan penalaran dalam menyelesaikan masalah matematis dan dapat membuat generalisasisesuai level 6 .
\end{abstract}

\section{Kata Kunci : kemampuan literasi matematika, gaya belajar sekuensial dan statistika}

\begin{abstract}
The purpose of this study is to describe the mathematical literacy skill in students with sequential learning styles in solving statistical problems. This research is a qualitative research. The process of collecting data in this study is done by giving a questionnaire learning style, providing problem-solving tasks, then choose one of the test results to be described. Data analysis is done by collecting data, reducing data, and verifying data.

The results obtained in this study are sequential subjects have literacy skills at level 1 that is Using knowledge to solve routine problems and yet still blom can solve the problem of the general context. The sequential subject has a literacy skill at level 2 that can solve problems with formulas. sequential subjects have not been able to carry out the procedures well in solving the problem and have not been able to choose a problem-solving strategy, according to level 3. Sequential subjects simply work effectively with the model and can choose and integrate different representations, then connect it with the real world according to level 4 . Sequential subjects have literacy skills at level 5 ie Working with models for complex situations. The subject has been able to show better variation of endurance with the coefficient of variation, but has not been able to use reasoning in solving mathematical problems and can make generalizations according to level 6.
\end{abstract}

Keyword : mathematics literacy skills, sequential learning styles and statistics 


\section{A. PENDAhuluan}

Kemampuan literasi matematika siswa Indonesia masih rendah. Hal ini terlihat dari hasil penelitian yang dilakukan PISA pada tahun 2000, 2003, 2006, dan 2009. Indonesia selalu masuk dalam 10 negara dengan kemampuan literasi matematika yang rendah OECD (2013). Hasil survey menunjukkan bahwa Indonesia selalu masuk dalam 10 negara dengan kemampuan literasi matematika yang rendah. Rata-rata skor internasional untuk kemampuan literasi matematika adalah 500 (level 3), sedangkan rata-rata skor literasi matematika siswa Indonesia adalah 375 (level 1). Level 1 adalah level terendah dari enam level kemampuan literasi matematika yang ditetapkan oleh PISA.

Organisasi internasional yang menilai kemampuan literasi matematika siswa, yaitu PISA (Programme for International Student Assessment). Fokus dari PISA adalah menekankan pada keterampilan dan kompetensi siswa yang diperoleh dari sekolah dan dapat digunakan dalam kehidupan sehari-hari dalam berbagai situasi (OECD, 2014).Penjelasan kerangka kerja PISA 2012 (OECD, 2013) tentang konstruk literasi matematika adalah sebagai berikut: dalam aspek konteks, literasi matematika diukur dalam konteks masalah dan tantangan yang dihadapi dalam dunia nyata seseorang (personal) yang berhubungan dengan kehidupan sehari-hari individu dan keluarga, societal yang berhubungan dengan komunitas, baik lokal, nasional atau global di mana seorang individu menjalani kehidupannya; occupational yang berhubungan dengan dunia kerja; dan scientific yang berhubungan dengan penggunaan matematika dalam ilmu pengetahuan dan teknologi.

Kemampuan literasi matematika tidak hanya dikhususkan bagi siswa, melainkan penting juga bagi mahasiswa karena pembelajaran matematika pada perguruan tinggi membutuhkan lebih banyak penalaran selain itu sebagai calon guru matematika mahasiswa dituntut mampu mempunyai pemikiran kritis, kreatif, logis dan sistematis. Pentingnya kemampuan literasi matematis tersebut ternyata belum sejalan dengan prestasi mahasiswa.

Literasi matematika didefinisikan sebagai kemampuan seseorang individu merumuskan, menggunakan, dan menafsirkan matematika dalam berbagai konteks. Literasi matematika membantu seseorang untuk mengenal peran matematika dalam dunia dan membuat pertimbangan maupun keputusan yang dibutuhkan sebagai warga Negara. OECD (2014).
PISA mengembangkan enam kategori kemampuan matematika siswa yang menunjukkan kemampuan kognitif dari siswa. Tingkatan kemampuan matematika menurut PISA disajikan pada tabel 1.1 berikut.

Tabel 1.1 Tingkatan Kemampuan Matematika

\begin{tabular}{|c|c|}
\hline Level & Deskripsi \\
\hline 1 & $\begin{array}{l}\text { Menggunakan pengetahuan untuk } \\
\text { menyelesaikan soal rutin, dan } \\
\text { dapat menyelesaikan masalah } \\
\text { yang konteksnya umum }\end{array}$ \\
\hline 2 & $\begin{array}{l}\text { Menginterpretasikan masalah dan } \\
\text { menyelesaikan dengan rumus }\end{array}$ \\
\hline 3 & $\begin{array}{l}\text { Melaksanakan prosedur dengan } \\
\text { baik dalam menyelesaikan soal } \\
\text { serta dapat memilih strategi } \\
\text { pemecahan masalah }\end{array}$ \\
\hline 4 & $\begin{array}{l}\text { Bekerja secara efektif dengan } \\
\text { model dan dapat memilih serta } \\
\text { mengintegrasikan representasi } \\
\text { yang berbeda, kemudian } \\
\text { menghubungkannya dengan dunia } \\
\text { nyata }\end{array}$ \\
\hline 5 & $\begin{array}{l}\text { Bekerja dengan model untuk } \\
\text { situasi yang kompleks serta dapat } \\
\text { menyelesaikan masalah yang } \\
\text { rumit }\end{array}$ \\
\hline 6 & $\begin{array}{l}\text { Menggunakan penalaran dalam } \\
\text { menyelesaikan } \\
\text { matematis, dapat membuat } \\
\text { generalisasi, merumuskan serta } \\
\text { mengkomunikasikan } \\
\text { temuannya }\end{array}$ \\
\hline
\end{tabular}

Dari uraian tersebut soal model pisa yang dikembangkan peneliti mengacu pada 6 level kemampuan yang dikembangkan oleh PISA dan diambil dari beberapa materi yang diajarkan pada mata kuliah statistika meliputi soal literasi matematis level 1 dan 2 termasuk kelompok soal dengan skala bawah yang mengukur kompetensi reproduksi. Soal literasi matematis level 3 dan 4 termasuk kelompok soal dengan skala menengah yang mengukur kompetensi koneksi. Sedangkan, soal literasi matematis level 5 dan 6 termasuk kelompok soal dengan skala tinggi yang mengukur kompetensi refleksi.

Untuk memecahkan masalah dengan kehidupan sehari-hari individu dan keluarga, setiap mahasiswa memiliki kecerdasan dan gaya berpikir yang berbeda-beda. Hal ini sesuai dengan yang diungkapkan Chatib (2010) bahwa setiap insan di dunia memiliki karakter dasar yaitu potensi, minat, dan bakat yang berbedabeda. Setiap mahasiswa memiliki tingkat kecerdasan yang berbeda-beda demikian juga dengan cara mereka untuk memahami suatu informasi dalam kemampuan literasi matematika 
sehingga cara seorang mahasiswa untuk memecahkan suatu masalah juga pasti akan berbeda tergantung dari bagaimana ia memahami permasalahan tersebut.

Terdapat berbagai model gaya belajar yang menggunakan tinjauan bagaimana cara mahasiswa memahami informasi salah satunya adalah model gaya belajar yang dikembangkan oleh Felder \& Silverman. Felder R.M.\& Silverman L.K (1988) mendefinisikan gaya belajar sebagai cara seorang individu untuk menerima, memproses, dan menggunakan informasi yang diperoleh. Dalam penelitian ini, peneliti akan memfokuskan kepada gaya belajar Felder \& Silverman pada dimensi pemahaman yaitu berupa gaya sekuensial karena merupakan konstruksi multi faset yang terdiri atas berpikir divergen.

Gaya belajar sekuensial adalah salah satu gaya belajar yang dikembangkan Felder dan Silverman (1988) mahasiswa dengan gaya belajar ini dapat dengan mudah beradaptasi dengan kurikulum atau lingkungan sekolah karena proses pembelajaran pada umumnya mengikuti tahap-tahapan yang sistematis dan runtut. Selain itu mahasiswa sekuensial lebih cenderung memahami sesuatu secara sistematis dengan mengikuti suatu alur. mahasiswa jenis ini lebih mudah mengingat dan memahami sesuatu jika pengajaran disampaikan secara sistematis mengikuti langkah-langkah yang logis. Gaya belajar sekuensial mahasiswa juga suka dengan jenis informasi yang rinci cenderung berpikir konvergen dan analitis (Felder \& Silverman, 1988).

Kenyataan di lapangan menunjukan bahwa sebagian besar mahasiswa mengalami kesulitan dalam belajar statitika dan literasi statistis. Hal ini sesuai dengan pengalaman peneliti, ketika mengajarkan statistika kepada mahasiswa, banyak mahasiswa yang mampu menyelesaikan soal statistika namun hanya sedikit yang mampu menjelaskan makna dari hasil yang diperoleh. Sejalan dengan hasil penelitian yang telah dilakukan (Lee,\& Litmanen 2004; Arteaga dkk, 2012) yang menyatakan bahwa peserta didik mengalami kesulitan dalam memahami dan menyajikan data bentuk histogram.

Berdasarkan uraian di atas, maka peneliti tertarik untuk Berdasarkan uraian tersebut maka peneliti ingin mengetahui bagaimana sebenarnya literasi matematika mahasiswa sekuensial dalam menyelesaikan masalah statistika. Adapun tujuan penelitian ini adalahUntuk mengetahui deskripsi kemampuan literasi matematika mahasiswa dengan gaya belajar sekuensial dalam menyelesaikan masalah statistika pada program studi pendidikan matematika.

\section{B. METODE}

Penelitian ini bertempat di Kampus Universitas KH A Wahab Hasbullah Jombang pada program studi pendidikan matematika yang merupakan kelas perkuliahan mata kuliah Statistika. Penelitian ini adalah penelitian kualitatif, yang bertujuan untuk menggambarkan kemampuan literasi matematika mahasiswa dengan gaya belajar sekuensial dalam mata kuliah Statistika. Subjek pada penelitian ini adalah mahasiswa semester IV. Instrumen penelitian ini berupa angket gaya belajar untuk menentukan gaya belajar mahasiswa, tugas pemecahan masalah statistika untuk mengukur kemampuan literasi matematika mahasiswa dan pedoman wawancara.

Adapun prosedur penelitian yang dilakukan peneliti sebagai berikut: (1). Kegiatan awal meliputi Penyusunan instrumen pendukung penelitian dan validasi instrument pendukung penelitian oleh validator (2) Kegiatan inti meliputi pemberian tes gaya belajar kepada mahasiswa, pemilihan subjek penelitian, pemberian tugas pemecahan masalah statistika, melakukan wawancara dan kegiatan triangulasi data. (3). Kegiatan akhir meliputi pengolahan analisis data, perumusan literasi matematika mahasiswa yang ditinjau dari gaya belajar sekuensial dan Penyusunan laporan penelitian. Langkah-langkah analisis data, dilakukan dengan tahapan: mengumpulkan data, mereduksi data, dan memverifikasi data

\section{HASIL DAN PEMBAHASAN}

Berikut ini hasil literasi mahasiswa dalam menyelesaikan masalah statistika.

\section{TPM 1}

Ibu Guru menyuruh andi mengambil sebuah buku dari lemari. Dia tidak bisa melihat bukunya. Banyak buku masing masing warna yang ada di dalam lemari ditunjukkan pada grafik berikut:

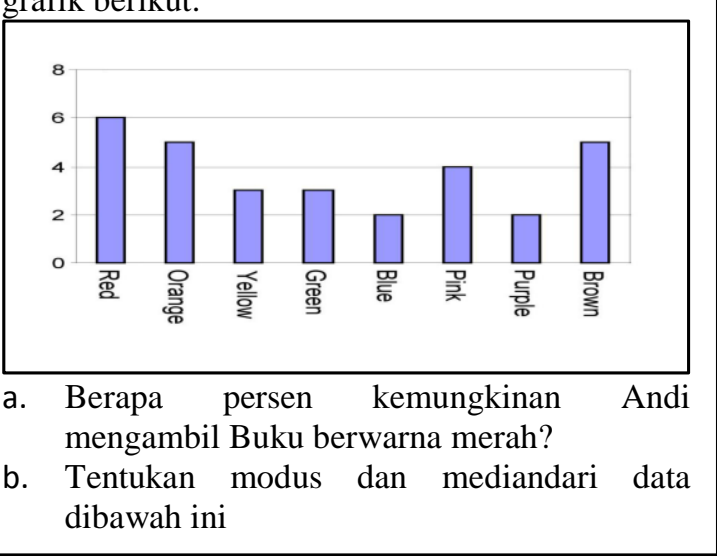




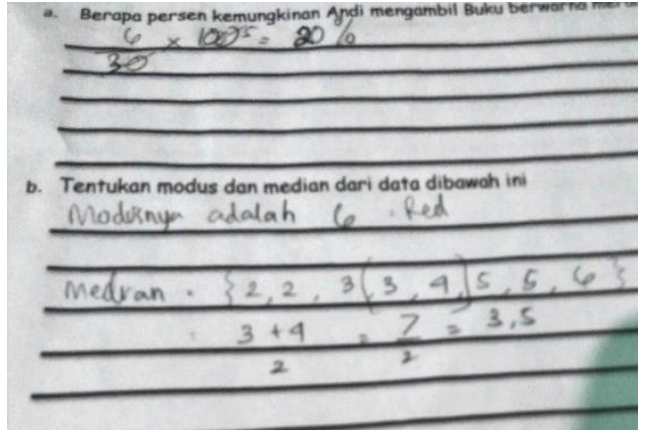

Pada Tahap penyelesaian TPM1 mahasiswa diminta menentukan persentase kemungkinan terambil buku berwarna merah dan menentukan modus dan median. Hasilnya subyek sudah bisa menunjukkan dengan baik persentase andi mengambil buku berwarna merah dan modus. Namun dalam menentukan median masih terdapat kesalahan dengan menyebutkan angka 5. Hal ini menunjukkan bahwa subjek sekuensial memiliki kemampuan literasi pada level 1 yang cukup baik yaitu Menggunakan pengetahuan untuk menyelesaikan soal rutin namun belum dapat menyelesaikan masalah yang konteksnya umum

\section{TPM 2}

Grafik berikut menunjukkan informasi ekspor barang dari Zedland sebuah negara dengan mata uang Zed

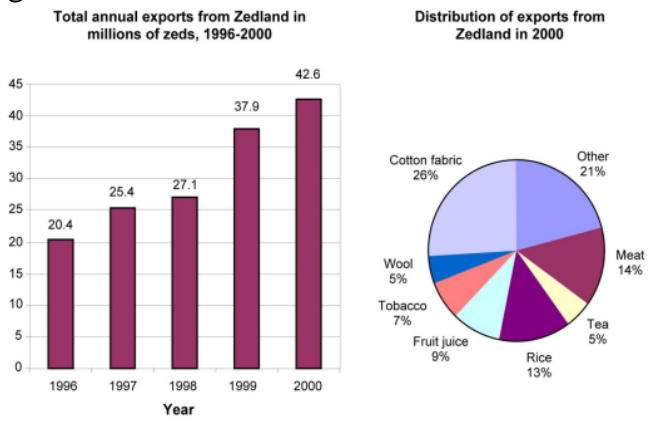

a. Berapakah jumlah Rata-rata ekspor (dalam juta Zed) pada tahun 1997-2000?

b. Jika jumlah eksport Sayuran pada tahun 1998 adalah 0,5 zed lebih besar dari jumlah ekspor wol dan tembakau pada

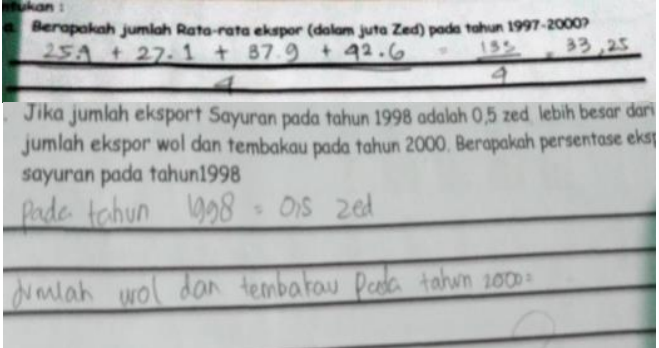

Rata-rata ekspor Hasilnya subyek sudah bisa menghitung nilai rata-rata dengan baik dan dapat menentukan jumlah daging yang diekspor lebih besar pada tahun 2000. Hal ini menunjukkan bahwa subjek sekuensial memiliki kemampuan literasi pada level 2 yaitu dapat menyelesaikan masalah dengan rumus. Pada soal b) mahasiswa diminta menentukan persentase ekspor sayuran pada tahun 1998. Siswa sekuensial belum bisa menentukan persentase ekspor pada tahun 1998 tampak bahwa hasil persentase yang dicapai 19,09\%. Hal ini menunjukkan siswa sekuensial belum bisa Melaksanakan prosedur dengan baik dalam menyelesaikan soal serta belum bisa memilih strategi pemecahan masalah, sesuai dengan level 3

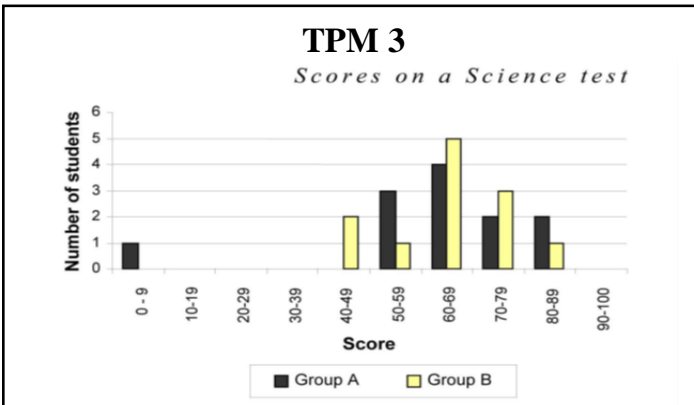

Diagram berikut menunjukkan hasil kuis STATISTIKA yang dibagi dua group yakni grup A dan grup B. Mean dari group A adalah 62,0dan Mean group B adalah 64,5. Mahasiswatuntasjika memperoleh nilai di atas atau sama dengan 50 .

Dosen mereka mengatakan bahwa group B lebih baik dari group A pada kuis kali ini. Seorang mahasiswa dari group A tidak setuju dengan pendapat dosennya itu. Mereka mencoba protes dan mengatakan bahwa group B tidak lebih baik.

Berikan komentar kalian secara matematik, menggunakan diagram di atas untuk mendukung mahasiswa dari group A.

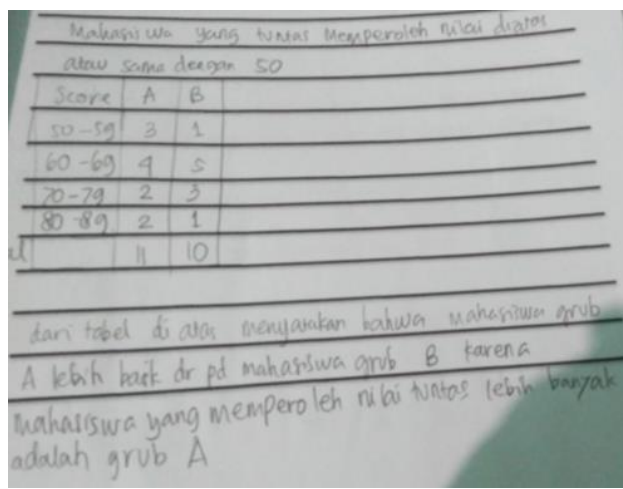

Pada Tahap penyelesaian TPM 3 mahasiswa diminta menggunakan diagram mendukung bahwa grup B tidak lebih baik dari 
grup A. Hasilnya subyek menunjukkan mahasiswa tuntas pada grup A sebanyak 11 orang dan mahasiswa yang tuntas pada grup B adalah 10 orang untuk mendukung bahwa grup A lebih baik dari grup B. Hal ini menunjukkan bahwa subjek bekerja secara efektif dengan model dan dapat memilih serta mengintegrasikan representasi yang berbeda sesuai dengan kemampuan matematika level 4.

\section{TPM 4}

Berikut data rata-rata pemakaain lampu pijar dan simpangan baku di toko Pasti Jaya

\begin{tabular}{||l|l|l||}
\hline $\begin{array}{c}\text { Merk } \\
\text { Lampu } \\
\text { Pijar }\end{array}$ & \multicolumn{1}{|c|}{$\begin{array}{c}\text { Rata-rata } \\
\text { pemakaian }\end{array}$} & \multicolumn{1}{|c|}{$\begin{array}{c}\text { Simpangan } \\
\text { Baku }\end{array}$} \\
\hline Alfa & 3500 jam & 1050 \\
\hline Beta & 9000 jam & 2000 jam \\
\hline Gamma & 7500 jam & 1500 jam \\
\hline
\end{tabular}

Peter ingn membeli lampu pijar dengan ketahanan variasi yang lebihbaik. Pilih lampu pijar apa yang harus di beli Peter

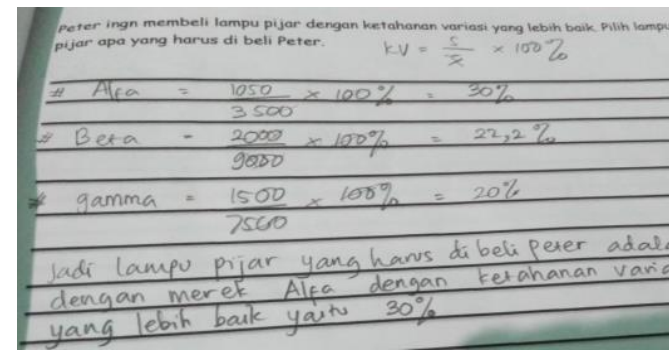

Pada Tahap penyelesaian TPM 4 mahasiswa diminta menentukan lampu apa yang harus dibeli peter untuk menentukan ketahanan variasi yang lebih baik. Hasilnya subyek telah dapat menunjukkan variasi ketahanan yang lebih baik hanya dengan satu cara yaitu dengan menentukan besar koefisien variasi. Hal ini menunjukkan subyek sekuensial dapat menyelesaikandengan model untuk situasi yang kompleks namun kurang Menggunakan penalaran dalam menyelesaikan masalah matematis, dapat membuat generalisasi, merumuskan serta mengkomunikasikan hasil temuannya sesuai level 6.

\section{PENUTUP}

\section{Kesimpulan}

Berdasarkan paparan hasil penelitian, hasil analisis dan pembahasan, maka dapat ditarik suatu kesimpulan sebagai berikut : a. subjek sekuensial memiliki kemampuan literasi pada level 1 yang cukup baik yaitu Menggunakan pengetahuan untuk menyelesaikan soal rutin dan namun masih belum dapat menyelesaikan masalah yang konteksnya umum

b. subyek sudah bisa menghitung nilai rata-rata dengan baik hal ini menunjukkan bahwa subjek sekuensial memiliki kemampuan literasi pada level 2 yaitu dapat menyelesaikan masalah dengan rumus namun subyek sekuensial belum bisa Melaksanakan prosedur dengan baik dalam menyelesaikan soal serta belum bisa memilih strategi pemecahan masalah, sesuai dengan level 3

c. subjek sekuensial cukup bekerja secara efektif dengan model dan dapat memilih serta mengintegrasikan representasi yang berbeda, kemudian menghubungkannya dengan dunia nyata seseuai dengan level 4.

d. subyek dapat menunjukkan variasi ketahanan yang lebih baik dengan satu cara. Hal ini menunjukkan bahwa subjek sekuensial cukup memiliki kemampuan literasi pada level 5 yaitu Bekerja dengan model untuk situasi yang kompleks namun kurang Menggunakan penalaran dalam menyelesaikan masalah matematis, dapat membuat generalisasi, merumuskan serta mengkomunikasikan hasil temuannya sesuai level 6 .

\section{Saran}

Berdasarkan hasil penelitian ini, maka peneliti menyarankan sebagai berikut.

1. Dalam penelitian ini literasi statistis hanya dilihat pada aspek kognitifnya saja, sedangkan aspek afektif belum dimunculkan. Peneliti menyarankan agar pada peneltian selanjutnya, elemen disposisi juga dapat dimunculkan. Sehingga, sikap dan minat mahasiswa terhadap statistika dan literasi matematika dapat dideskripsikan dengan jelas.

2. Perlu mengembangkan indikator ketercapaian literasi matematika yang dapat digunakan untuk melihat sejauh mana literasi matematika mahasiswa. Sehingga, dosen dapat merancang pembelajaran yang efektif terkait dengan kemampuan literasi mahasiswa

\section{DAFTAR PUSTAKA}

Chatib, Munif. (2010). Sekolahnya Manusia. Bandung: Kaifa

Felder, R. M. \& Silverman, L. K. (1988). "Learning Styles and Teaching Styles inEngineering Education. " Engineering 
Education, $\quad 78, \quad 674-681$. http://www4.ncsu.edu/unity/lockers/users/f /felder/public/Papers/Creative_Engineers.p df. Diunduh pada tanggal 2 juni 2017

Johar, Rahmah. 2012. Domain Soal PISA untuk Literasi Matematika. (Online).

Tersedia

http://www.jurnal.unsyiah.ac.id/peluang/arti cle/download/1296/1183.

Diakses 2 juni 2017

Litmanen, T., Lonka, K., Inkinen, M.,Lipponen, L. \& Hakkarainen, K.. 2012."Capturing Teacher Students' Emotional Experiences in Context: Does Inquiry-Based Learning Make a Difference?"Instr Sci. Vol 40:1083-1101

OECD. 2013. Draft PISA 2012 Assessment Framework. (Online). Tersedia: http://www.oecd.org/dataoecd/61/15/462419 09.pdf. Diakses 2 Juni 2017

OECD, PISA 2014 Results: What Students Know and Can Do - Student Performancein
Mathematics, Reading and Science (Volume I, Revised edition, February 2014), Paris: OECD Publishing, 2014.

1 Khusnul Khotimah, lahir pada 29 Juni 1986, menyelesaikan studi S1 Pendidikan Matematika di IAIN Tulungagung dan menempuh S2 Prodi Pendidikan Matematika di Pascasarjana UNESA Surabaya, Sejak 2015 s.d Sekarang mengabdi untuk belajar dan mengajar di Fakultas Ilmu Pendidikan Universitas KH. A. Wahab Hasbullah Jombang.

${ }^{2}$ M. Farid Nasrulloh, lahir pada 13 April 1987, menyelesaikan studi S1 Pendidikan Matematika di UIN Sunan Kalijaga Yogyakarta, dan menempuh S2 Prodi Pendidikan Matematika Pascasarjana UNY. Sejak 2015 s.d Sekarang mengabdi untuk belajar dan mengajar di Fakultas Ilmu Pendidikan Universitas KH. A. Wahab Hasbullah Jombang. 